\title{
The Fear of Foreign Accent and the Endangerment of Igbo Language
}

\author{
Chidi Nnamdi Igwe \\ University of Regina, Regina, Canada
}

\begin{abstract}
Many world languages and dialects today are endangered. The threat of language endangerment has caught the attention of many scholars like Fishman (2001), Odinye and Odinye (2010), and international organizations like the UNESCO (United Nations Educational, Scientific, and Cultural Organization), which have proposed a model for classifying less privileged languages and dialects. The future of the Igbo language of south-eastern Nigeria is not too certain. Duruaku (2004) showed that the Igbo people portray some negative attitudes toward their language. Such attitudes hamper language maintenance and preservation. This paper focuses on the current status of Igbo language and examines the roles of linguistic perceptions in Igbo language endangerment.

Keywords: language endangerment, language maintenance and preservation, Igbo language and dialects, language perception, language acquisition
\end{abstract}

\section{Introduction}

The Igbo Language and Cultural School Online was established in 2009 to offer heritage language lessons to Canada-born children, whose parents migrated from Nigeria. Through the Igbo Language School Online (www.igboteacher.com), the author administered a survey in 2012, in which 252 students participated. Three different surveys were created, targeting three different levels of students. Out of the 172 students, who participated in the entry level surveys, 170 students completed the survey and two students went half-way. The answers were collected anonymously, but some students could self-identify by providing their email addresses. The respondents ranged from ages 16 to 45 and represented mostly United States, Canada, and the United Kingdom as shown in Table 1.

The primary aim of the study was to determine certain factors that may militate against students' success, especially because they are taking the Igbo language courses online. One of the major questions of the entry level survey that counted 172 respondents is: Why do you want to learn Igbo language? This question was important to evaluate whether their reasons for choosing to learn the language were strong enough to encourage the students to devote at least 20 minutes per day to complete a five-week course online. This question also became the central to this study, because most students answered in ways that pointed out and reproached some negative attitudes of their parents towards their L1 (mother tongue). Some indicated that their parents did not do enough to teach them the language when they were young, and some others said that their parents

Chidi Nnamdi Igwe, Ph.D., Department of French, University of Regina. 
categorically forbade them from learning the language. But now that these students are older, they have realized what an important connection the Igbo language is between them and their routes. When the author compared the data from the online respondents with our real experience with the parents at the Igbo Language and Cultural School of Regina, the author decided to carry out this study to further explore the reasons why some Igbo-speaking parents show diminishing interest in transferring their L1 to their children.

Table 1

Entry Level Survey Sampling of Respondents by Country

\begin{tabular}{lclc}
\hline Country of origin & $\begin{array}{l}\text { Number of students who completed } \\
\text { the survey }\end{array}$ & $\begin{array}{l}\text { Number of students who did not } \\
\text { complete the survey }\end{array}$ & Total \\
\hline Australia & 1 & 0 & 1 \\
Austria & 2 & 0 & 2 \\
Canada & 6 & 0 & 6 \\
Germany & 3 & 0 & 3 \\
Nigeria & 1 & 0 & 1 \\
Republic of Korea & 1 & 0 & 1 \\
Spain & 1 & 0 & 1 \\
Switzerland & 1 & 0 & 1 \\
United Kingdom & 16 & 0 & 16 \\
United States of America & 138 & 2 & 140 \\
\hline Total & & & 172 \\
\hline
\end{tabular}

The author designed a questionnaire administered to about 178 Igbo-speaking parents in Canada and the US, some of whom included parents of the online students. The answers obtained varied from lack of time, lack of study materials to lack of awareness of the existence of any Igbo school. The one answer that stood out was what can be described as the "fear of foreign accent". Some of the parents who participated in the survey have been told many times before that they spoke Canadian or American English with a foreign accent. A good number of people that migrate to new linguistic societies often try to integrate by learning the primary languages of communication in their new societies. Most of the parents interviewed migrated from Nigeria already speaking English, but have worked hard over the years to undergo phonetic rebirth, eliminate their Nigerian accent, and adapt to the Canadian or American accent in order to integrate into their new linguistic communities.

\section{Canadian Accent, American Accent}

The parents had a broader perception of the term "Canadian accent" or "American accent". This perception did not take into account the regional variations of English that make someone from Texas articulate some English phonemes in ways slightly different from someone from New York or California, the same way in which someone from Toronto does not sound exactly like someone from Regina, even though they both speak the same Canadian English. However, even though some of the parents perceived their imported Nigerian accent as inferior to the new ones they are trying to adapt to in North America, most of these parents have not had any success with this phonetic integration, because as we interacted with them, in addition to apparent idiosyncrasies, they still articulated lots of distinct English phonemes the Nigerian way. Yet, they continue to struggle to adapt to what they see as a superior and more acceptable way of articulating English speech sounds. 


\section{Foreign Accent}

Neurologists such as Kurowski, Blumstein, and Alexander (1996) and Akhlaghi, Jahangiri, Azarpazhooh, Elyasi, and Ghale (2011) have studied foreign accent syndrome, which has been described in the following way: "Foreign accent syndrome (FAS) is a rare neurologically—or psychotically-based speech production disorder in which a patient produces the phonetic features of his or her L1 with an accent regarded as foreign by speakers of the same speech community" (Akhlaghi et al., 2011, p. 562). We take foreign accent from a purely sociolinguistics viewpoint. Members of a given speech community share certain phonetic characteristics in the way they articulate certain phonemes of their language. From a sociolinguistic perspective, accent is the pronunciation pattern of speech sounds peculiar to a given speech community. The concept of speech accent supposes the existence of phonemic variations and any variation spoken in a speech community where it is quite uncommon would usually be considered as foreign to that speech community. Immigrants are one of the major categories of people often called out for foreign accent, because their patterns of articulation of phonemes are often distinct from native speakers of the variety of language spoken in their host community. Thus, although certain members of a speech community may use the concept of foreign accent to stigmatize those they consider as "other", yet it is usually not conceived as a speech disorder. It is a phonetic variant of a language spoken in an unfamiliar ground.

Some parents revealed that they had thought and were afraid that, if their children learned Igbo, they equally would end up speaking English with a foreign accent. Related language acquisition studies have focused mainly on the concept of "foreign accent" as one of the remarkable aspects of L2 (Second Language) and FLL (foreign language learning). Flege, Munro, and MacKay (1995), Piske, MacKay, and Flege (2001), Munro and Derwing (2001), and Boyd (2003), for instance, were based on the accent problem of immigrant students and teachers and how native speakers react to their accented speeches. Pronunciation is a very important aspect of language acquisition and mastery. The way speech sounds are articulated can influence the meaning and communicative powers of such sounds, and L1s often have noticeable phonetic influence on how L2 learners articulate L2 sounds.

The study revealed that the parents interviewed were afraid of the reverse effect of the above-noted language influence-that if the children learned Igbo language, they would speak English with a foreign accent. Compared to their children, the parents have a different linguistic background. For the parents, Igbo was their L1, and most of them learned English as official language of communication in Nigeria, starting from elementary school. Most of them were taught English in Nigeria by other Nigerians, who also learned English from other Nigerians. At the elementary and secondary schools, most of the parents had no access to audiovisual language learning materials produced by native speakers, nor any contact with native speakers of the Canadian or American English until they grew into professional adults and migrated to North America and began to bear children. For the children, it is the opposite. They were born in Canada and United States and have Canadian or American English as their L1. There are limited studies on how the acquisition of L2 can affect the phonetic structure and the articulation of L1 by children.

Studies have shown that the more languages children learn, the larger their world view, and the better they are likely to perform in other subjects. When we sampled the children that are learning Igbo at the Igbo 
Language and Cultural School of Regina through audiovisual recording of their articulation on various topics in both English and Igbo, none of them spoke English with a foreign accent; rather, they all spoke Igbo with an English accent. This shows that L1 definitely influences phonetic performance in L2, but it does not show that L2 has major influence on how L1 is articulated, because L1 has already been acquired and mastered before the acquisition of $\mathrm{L} 2$ as a foreign language.

Studies such as Odinye and Odinye (2010) suggested that this diminishing interest from parents in their children's acquisition of Igbo language is not unique to the Igbo communities in Canada and US. It is even worse in Nigeria, where Igbo language faces severe influences from the English language. Language has been used as the primary mode of ethnic identity. Expressions like English people and French people carry elements of language-based ethno-cultural identity. One of the major ways a people can lose their ethno-cultural identity is through the loss of their language. Odinye and Odinye (2010) saw language as an indispensable tool for human communication and national development. They also observed that most human activities make use of language and that man is not complete without language. One of the factors causing the diminishing interest in the acquisition of Igbo language remains the uncontrollable influences of English on Nigerian indigenous languages.

\section{Igbo Language Endangerment}

According to Odinye and Odinye (2010, p. 89), language endangerment can be defined as a condition whereby the socio-economic, political, technological, cultural, and religious ecologies have altered to a point where some language species cannot survive or thrive in them. The social, cultural, and economic situation of Nigeria has changed rapidly in the last few years favouring more and more the use of English language. The increasing valorization of English language forces many syntactical and morphological changes upon the indigenous languages. Igbo language shows insufficient lexical creativity to respond adequately to the naming needs that come with introducing new products and concepts into the indigenous cultures. For instance, Odinye and Odinye (2010, p. 89) noted that the use of Igbo language in government, schools, churches, meetings, campaigns, conversations, or at homes is continuously decreasing. Since linguistic competence increases with practice, the mastery of the language is constantly decreasing among young people. Thus, it is becoming more and more difficult to find young people who can speak Igbo fluently without resorting to a linguistic phenomenon known as "Engli-Igbo", a form of code-switching or code mixing exemplified in Table 2, inspired by Obiamalu and Mbagwu (2008, pp. 28-30).

Table 2

Example of Code-Switching by Young Igbo Speakers

\begin{tabular}{|l|l|l|}
\hline Code-switching & Authentic Igbo & English \\
\hline Abịara $\mathrm{m}$ na your house yesterday & Abịara m na be gị ụnyahụ & I came to your house yesterday \\
\hline Fela na ecritisizi onye ọbụla & Fela na-akọtọ onye ọbụla & Fela criticizes everybody \\
\hline Jesus turnụrụ water ọ ghọrọ wine & Jesus mere mmiri ọ ghọrọ mmanya & Jesus turned water into wine \\
\hline
\end{tabular}

Igbo language is spoken by over 30 million people living predominantly in Anambra, Ebonyi, Enugu, Imo, Abia, and parts of Delta and Rivers States of Nigeria, and hundreds of thousands of immigrants of Igbo origin 
living in other parts of Africa, Europe, North America, and Asia. Nigeria is a West African nation with a population of about 140 million people. English is the official language of Nigeria, retained after the British colonization of Nigeria to foster the unity of a country with a high level of linguistic diversity, where, according to Crozier and Blench (1992), Grimes (2000), and Heine and Nurse (2000), over 400 languages and dialects are spoken. The national policy in education recognizes English as the official language of communication, education, commerce, etc., and three national languages, Hausa, Igbo, and Yoruba. This multilingual context created the first set of challenges for Igbo, which is now struggling to survive as one of the three national languages. UNESCO (United Nations Educational, Scientific, and Cultural Organization) report on endangered indigenous languages says that Igbo language faces risk of possible extinction in the next 50 years. The question may be: How can a language spoken by over 30 million people be said to be endangered?

\section{Igbonization}

The effect of English on Igbo language leads to the concept of "Igbonization", which, although has been rebuked by many Igbo linguists, remains a major process of assigning words to meanings. With the current technological advancement and increasing influence of the Anglo-American culture in everyday life in Nigeria, one of the major processes of lexical creativity in Igbo has become simply borrowing English words and subjecting them to minor phonetic and orthographical modification. This linguistic phenomenon is prevalent in the following informatics lexicon used in the Igbo style guide proposed for Microsoft product localization (see Table 3).

Table 3

Igbo Style Guide for Microsoft Product Localization

\begin{tabular}{|c|c|c|c|}
\hline US command & US English shortcut key & Igbo command & Igbo shortcut key \\
\hline $\begin{array}{l}\text { Display pop-up menu for the } \\
\text { window }\end{array}$ & Alt + Spacebar & Gosịpụta mkpalite menù màkà window & Alt + Spacebar \\
\hline $\begin{array}{l}\text { Display pop-up menu for the active } \\
\text { child window }\end{array}$ & Alt + - & $\begin{array}{l}\text { Gosịputa mkpalite menù màkà mwake } \\
\text { window ntà }\end{array}$ & Alt + - \\
\hline $\begin{array}{l}\text { Display property sheet for current } \\
\text { selection }\end{array}$ & Alt + Enter & $\begin{array}{l}\text { Gosịpụta ibeakwụkwọ njìrìmaraihē màkà } \\
\text { nhọpụta ọụụ }\end{array}$ & Alt + Enter \\
\hline Close active application window & Alt + F4 & Mechie mwake ntinyeọrụ window & Alt + F4 \\
\hline $\begin{array}{l}\begin{array}{l}\text { Switch to next window within } \\
\text { (modeless-compliant) application }\end{array} \\
\end{array}$ & Alt + F6 & $\begin{array}{l}\text { Bànye na window ọzọ nọketere (mkpesa } \\
\text { enweghi model) ntinyeọụ }\end{array}$ & Alt + F6 \\
\hline $\begin{array}{l}\text { Capture active window image to the } \\
\text { clipboard }\end{array}$ & Alt + Prnt Scrn & $\begin{array}{l}\text { Nweta nnyinyo mwake window na bọd } \\
\text { ntipanye }\end{array}$ & Alt + Prnt Scrn \\
\hline \begin{tabular}{|l|}
$\begin{array}{l}\text { Capture desktop image to the } \\
\text { clipboard }\end{array}$ \\
\end{tabular} & Prnt Scrn & $\begin{array}{l}\text { Nweta nnyinyo desktọpp na bọod } \\
\text { ntipanye }\end{array}$ & Prnt Scrn \\
\hline Access start button in taskbar & Ctrl + Esc & Nnwetaohere mbido ọdụmbi n'ogweọrụ & Ctrl + Esc \\
\hline Display next child window & $\mathrm{Ctrl}+\mathrm{F} 6$ & Gosịpụta window ntà ọzọ & $\mathrm{Ctrl}+\mathrm{F} 6$ \\
\hline Display next tabbed pane & $\mathrm{Ctrl}+\mathrm{Tab}$ & Gosịpụta taabụ panù ọzọ & $\mathrm{Ctrl}+\mathrm{Tab}$ \\
\hline
\end{tabular}

Originally, Igbo language has four market days, which form the days of the Igbo $i z u$ (week) as follows: Eke, Orie, Afo, and Nkwo. This aspect of the culture is continuously modified or even eliminated by the influence of English language, thus Western calendar has been adopted and igbonized (meaning to adapt a borrowed linguistic unit to the Igbo language system through morphological and phonetic modification of the borrowed unit). Today, it is hard to find any young Igbo person who uses Eke, Orie, Afo, and Nkwo. Table 4 shows the borrowing structure highlighted above. 
Table 4

Days of the Week in Igbo

\begin{tabular}{|l|l|}
\hline English & Igbo \\
\hline Monday & Mọndee \\
\hline Tuesday & Tuzdee \\
\hline Wednesday & Nwenezdee \\
\hline Thursday & Tọzdee \\
\hline Friday & Frayịdee \\
\hline Saturday & Satọdee \\
\hline Sunday & Sọndee \\
\hline
\end{tabular}

The Igbo language morphological system has acquired lots of igbonized English words in technical domains and below are some examples from the metric system. In the following examples, English words have been borrowed with minor phonetic and orthographic change (see Table 5).

Table 5

Metric System in Igbo

\begin{tabular}{|l|l|}
\hline English & Igbo \\
\hline Kilometer & Kilomita \\
\hline Meter & Mita \\
\hline Decimeter & Desimita \\
\hline Centimeter & Sentimita \\
\hline Millimeter & Milimita \\
\hline Liter & Lita \\
\hline
\end{tabular}

Some of the students' answers to the central question of why they wanted to learn Igbo blamed their parents for depriving them the opportunity to learn Igbo when they were young. This indirectly reveals the parents' attitude towards the language. Bainbridge (1994, p. 400) defined attitude as "the positive or negative evaluation of an object". Othman and Bashir (2000, p. 449) thought that community language attitudes denote the positive-negative evaluations of individual languages or group of languages, with regard to such dimensions as loyalty, prestige, utility, or aesthetics. Duruaku (2004, p. 102) observed that the Igbo people portray negative attitudes toward their language. According to Eme (2004, p. 304), some Igbo parents, especially the literate ones, do not speak Igbo to their children even at home. In some cases, the parents ban their children from using Igbo to communicate among themselves because speaking Igbo would probably cause the children to speak English with a foreign accent. These parents prefer their children to use English which is a more prestigious language and can open more doors of opportunities than the Igbo language.

\section{Conclusions}

Sociolinguistic factors such as language perception, the desire to belong, education, government policies, and globalisation create negative attitudes towards minority languages. Odinye and Odinye (2010) showed that when the government of a country formulates a language policy which recognizes one language as the official language of that nation, the given language will definitively attract favourable attitudes from the people since it 
services as a means of carrying out official functions. In Nigeria and other places like North America, where Igbo speakers live, English is the dominant language of daily communication, administration, education, and commerce, and this kind of linguistic situation favours English language to the detriment of less privileged languages. Igbo parents develop favourable attitude toward English language and often abandon the use of Igbo language at homes. How can a language survive extinction if it is not being transferred to future generations?

\section{References}

Akhlaghi, A., Jahangiri, N., Azarpazhooh, M. R., Elyasi, M., \& Ghale, M. (2011). Foreign accent syndrome: Neurolinguistic description of a new case. 2011 International Conference on Languages, Literature and Linguistics. IPEDR, 26, 562-567.

Bainbridge, W. S. (1994). Social psychology. In R. E. Asher \& J. M. Y. Simpson (Eds.), The encyclopedia of language and linguistics (Vol. 71, pp. 3998-4004). Oxford: Pergamon Press.

Boyd, S. (2003). Foreign-born teachers in the multilingual classroom in Sweden: The role of attitudes to foreign accent. International Journal of Bilingual Education and Bilingualism, 6(3), 283-295.

Crozier, D. H., \& Blench, R. M. (1992). An index of Nigerian languages (2nd ed.). Dallas: Summer Institute of Linguistics, Inc..

Duruaku, C. (2004). Folktala and contemporary Igbo families. In J. I. Okonkwo (Ed.), Journal of Nigerian Language and Culture, 6 , 98-102. Owerri: Association of Promoting Nigerian Languages and Culture.

Eme, C. A. (2004). Improving Igbo language use at homes and communities. In P. C. Nzomiwu \& J. E. Madu (Eds.), Unizik Journal of Arts and Humanities (pp. 302-313). Awka: A Global Communications Production.

Fishman, J. (2001). Why is it so hard to save a threatened languages?. Reversing language shift revisited: A 21 st century perspective. Clevedan: Multilingual Matters.

Flege, J. E., Munro, M. J., \& MacKay, I. R. A. (1995). Factors affecting strength of perceived foreign accent in a second language. Journal of the Acoustical Society of America, 97, 3125-3134.

Grimes, B. F. (2000). Ethnologue: Languages of the world (14th ed.). Dallas: SIL International.

Heine, B., \& Nurse, D. (2000). African languages: An introduction. Cambridge: Cambridge University Press.

Kurowski, K., Blumstein, S. E., \& Alexander, M. (1996). The foreign accent syndrome: A reconsideration. Brain and Language, 54, $1-25$.

Microsoft. (2011). The Igbo style guide. Retrieved from http://www.microsoft.com/Language/en-US/StyleGuides.aspx

Munro, M. J., \& Derwing, T. (2001). Modelling perceptions of the comprehensibility and accentedness of L2 speech: The role of speaking rate. Studies in Second Language Acquisition, 23, 451-468.

Nwadike, I. U. (2008). Igbo language and culture! Whither bound! (Asusu na Omenala Igbo: Ije Anaa?). In R. N. Umeasiegbu (Ed.), F. C. Ogbalu memorial lecturers (Vols. 1 \& 3, pp. 5-59). In Association with Nnamdi Azikiwe University, Awka. Onitsha: Vasity Puiblishing Co. Ltd..

Obiamalu, G., \& Mbagwu, D. (2008). Motivations for code-switching among Igboenglish bilinguals: A linguistic and sociopsychological survey. African Journals Online (AJOL), 5, 27-39.

Odinye, I., \& Odinye, I. (2010). Preventing the extinction of Igbo language. African Journals Online (AJOL), 7, 85-93.

Othman, A., \& Bashir, A. (2000). Language choice and use in Maiduguri. In S. B. Ajulo \& The Festschrift Committee (Eds.), Language in society: Festschrift in honour of professor Conrad Max Benedict Brenn. Lagos: University of Lagos Press.

Piske, T., MacKay, I. R. A., \& Flege, J. E. (2001). Factors affecting degree of foreign accent in an L2: A review. Journal of Phonetics, 29, 191-215. 